\title{
Chemical composition and in situ degradability of silages from dual- purpose sorghum hybrids
}

\section{Composição química e degradabilidade in situ de silagens de híbridos de sorgo duplo propósito}

\author{
Alex Lopes da Silva ${ }^{1 *}$; Ricardo Loiola Edvan²; Leilson Rocha Bezerra ${ }^{3}$; \\ Rafael Felippe Ratke ${ }^{4}$; José Avelino Santos Rodrigues ${ }^{5}$; Diego Sousa Amorim ${ }^{6}$; \\ Romilda Rodrigues do Nascimento ${ }^{7}$; Marcos Jácome de Araújo ${ }^{2}$
}

\begin{abstract}
The objective was to determine chemical composition and in situ degradability for silages of dual-purpose sorghum hybrids. Twenty-five hybrids of double-purpose sorghum were investigated in a randomized block design with three replicates. Ammoniacal nitrogen $\left(\mathrm{NH}_{3}-\mathrm{N}\right), \mathrm{pH}$, chemical composition of the silage and in situ degradability were determined. Silage of the hybrids 9929012, 947216, 947030, 947254, 947072, 947252, 12F042066, 1141570 and 1141562 presented greater dry matter content, ranging from 402.9 to $470.7 \mathrm{~g} \mathrm{~kg}^{-1}$. The greatest crude protein content was presented by silages from the hybrids 9929036, 9929030, 12F042224, FEPAGRO19, FEPAGRO11, 9929026, 947030, 947072, 947252, 12F042226 and BRS Ponta Negra. The silage of hybrid 1141562 exhibited the lowest neutral detergent fiber content $\left(588 \mathrm{~g} \mathrm{~kg}^{-1}\right)$. The highest values of dry matter and crude protein degradability were observed in the silages of the hybrids 9929030, 947252, 947072, 12F042066 and 12F042226. The use of ensilage of the 9929030 and 12F042226 hybrids is recommended because these silages present a better chemical composition of dry matter, crude protein and neutral detergent fiber and better dry matter and crude protein degradability.
\end{abstract}

Key words: Crude protein. Forage conservation. Nutritive value. Sorghum bicolor.

\section{Resumo}

Objetivou-se determinar composição química e degradabilidade in situ das silagens de híbridos de sorgo duplo propósito. Foram estudados vinte e cinco híbridos de sorgo duplo propósito em delineamento

\footnotetext{
1 Discente de Doutorado, Programa de Doutorado Integrado em Zootecnia, Universidade Federal da Paraíba, UFPB, Departamento de Zootecnia, Areia, PB. Brasil. E-mail: alex.lopes77@hotmail.com

2 Profs., Universidade Federal do Piauí, UFPI, Departamento de Zootecnia, Bom Jesus, PI, Brasil. E-mail: edvan@ufpi.edu.br; jacome@ufpi.edu.br

3 Prof., Universidade Federal de Campina Grande, UFCG, Centro de Saúde e Tecnologia Rural, Patos, PB, Brasil. E-mail: leilson@ ufpi.edu.br

4 Prof., Universidade Federal do Mato Grosso do Sul, UFMS, Departamento de Agronomia, Chapadão do Sul, MS, Brasil. E-mail: rfratke@gmail.com

5 Pesquisador, Empresa Brasileira de Pesquisa Agropecuária, EMBRAPA Milho e Sorgo, Sete Lagoas, MG, Brasil. E-mail: avelino.rodrigues@embrapa.br

6 Discente de Doutorado, Programa de Doutorado Integrado em Zootecnia, Universidade Federal do Ceará, UFC, Departamento de Zootecnia, Fortaleza, CE, Brasil. E-mail: diego.zootecnista@hotmail.com

7 Discente, Curso de Mestrado do Programa de Pós-graduação em Ciência Animal, UFCG, Centro de Saúde e Tecnologia Rural, Patos, PB, Brasil. E-mail: romilda0155@hotmail.com

* Author for correspondence
} 
de blocos casualizados com três repetições. Foram determinados nitrogênio amoniacal $\left(\mathrm{NH}_{3}-\mathrm{N}\right), \mathrm{pH}$, composição química e degradabilidade in situ da silagem. As silagens dos híbridos 9929012, 947216, 947030, 947254, 947072, 947252, 12F042066, 1141570 e 1141562 apresentaram maior teor de matéria seca, variando de 402,9 a 470,7 $\mathrm{g} \mathrm{kg}^{-1}$. O maior teor de proteína bruta foi apresentado pelas silagens dos híbridos 9929036, 9929030, 12F042224, FEPAGRO19, FEPAGRO11, 9929026, 947030, 947072, 947252, 12F042226 e BRS Ponta Negra. A silagem do híbrido 1141562 apresentou o menor teor de fibra em detergente neutro $\left(588 \mathrm{~g} \mathrm{~kg}^{-1}\right)$. Os maiores valores de degradabilidade da matéria seca e proteína bruta foram observados nas silagens dos híbridos 9929030, 947252, 947072, 12F042066 e 12F042226. Recomenda-se o uso da ensilagem dos híbridos 9929030 e 12F042226, pois estas silagens apresentam melhor composição química de matéria seca, proteína bruta e fibra em detergente neutro e melhor degradabilidade da matéria seca e proteína bruta.

Palavras-chave: Conservação de forragem. Proteína bruta. Sorghum bicolor. Valor nutritivo.

\section{Introduction}

The use of sorghum silage in animal feed in the dry seasons of the year is a way of sustaining herds of ruminants raised on pasture. The use of sorghum silage has been increased because the corn crop presents a lower water shortage tolerance than the sorghum crop. The tolerance of sorghum to water restriction is probably related to water uptake and transport (ARGENTA et al., 2014; LIU et al., 2014).

Silage production from double-purpose sorghum is an interesting option because in addition to increasing productivity, sorghum can provide better silages due to a greater quantity of grains, chemical composition and degradability values. The nutritional value and productivity provided are crucial forage characteristics for animals (SUZUKI et al., 2010). In animal production, nutrition is an essential point and depends on four factors: nutritional requirements, composition of the feed, digestibility of the feed and the amount of nutrients that the animal ingests (THOMAS et al., 2013).

Values observed by Pires et al. (2009) for the degradation potential ranged from $592.0 \mathrm{~g} \mathrm{~kg}^{-1}$ for the CMSXS165 silage to $309.0 \mathrm{~g} \mathrm{~kg}^{-1}$ for the BR700 silage. At 24 hours, Cavalcante et al. (2012) observed similarity between maize and sorghum in the in natura form. In the composition of hybridtype sorghum silages, Avelino et al. (2011) found values of 304 and $16.1 \mathrm{~g} \mathrm{~kg}^{-1}$ for the DM and EE, respectively, for the Volumax silage and 365 and $20.5 \mathrm{~g} \mathrm{~kg}^{-1}$ for the DM and EE, respectively, in the AG-2005. In the case of double-purpose sorghum hybrids, variations may exist in both the degradation and composition, and selecting among the hybrids studied is necessary to achieve better results. Chemical composition varies among the hybrids, and ruminal degradation can be used to identify the best silages. Thus, this research was developed with the objective of determining the chemical composition and the in situ degradability among silages of double-purpose sorghum hybrids.

\section{Material and Methods}

The experiment was conducted at the Federal University of Piauí, Campus Professora Cinobelina Elvas, Bom Jesus City, Piauí State, Brazil (0904'28”S, 4421'31'W, 277 m altitude) from January to August 2014 and under strict accordance with the National Council Guide to Animal Experimentation Control (CONCEA). The ethics committee of the Federal University of Piauí approved the experimental protocol (protocol number: 016/14). The climate is characterized as hot and semi-humid, with a minimum temperature of $18{ }^{\circ} \mathrm{C}$ and maximum of $36{ }^{\circ} \mathrm{C}$ and an average annual precipitation of $900 \mathrm{~mm}$ (ANDRADE JUNIOR et al., 2004).

Twenty-five double sorghum hybrids (grain and silage production) supplied by Embrapa Maize and Sorghum (Sete Lagoas, Minas Gerais, Brazil) were used: 9929036, 9929030, 12F042224, 12F042150, FEPAGRO18, FEPAGRO19, FEPAGRO11, 
9929012, 9929026, 947216, 947030, 947254, 947072, 947252, SF15, SF11, SF25, PROG134IPA, 12F042140, 12F042066, 12F042226, 12F042422, 12F042226, BRS 506 and BRS Ponta Negra.

The total area of $620 \mathrm{~m}^{2}$ was divided into 75 plots of $4.00 \mathrm{~m}^{2}$ each $(2.00 \times 2.00 \mathrm{~m})$, with $0.50 \mathrm{~m}$ spacing between rows, totaling five rows per parcel and $2.00 \mathrm{~m}$ between blocks. Seeds of all hybrids were distributed in grooves with depths of approximately $3.00 \mathrm{~cm}$, with 20 seeds per meter, with a population in the harvest of 140,000 to 170,000 plants ha $^{-1}$ according to the recommendations proposed by Ribas (2007).
The fertilization was carried out according to the soil analysis performed. The following fertilizers were applied at planting: $40.0 \mathrm{~kg} \mathrm{P}$ $\mathrm{ha}^{-1}$ (single superphosphate) and $60.0 \mathrm{~kg} \mathrm{~K} \mathrm{ha}{ }^{-1}$ (Potassium chloride). Forty days after planting, $70.0 \mathrm{~kg} \mathrm{~N} \mathrm{ha}^{-1}$ (urea) was applied according to the recommendations of Sousa and Lobato (2004). All plants were cut manually from the plots, then processed in a stationary forage, it was considered the moment of harvest the farinaceous grain, which ranged from 106 to 134 days after planting (Table 1).

Table 1. Characterization of double purpose sorghum hybrids.

\begin{tabular}{lcccc}
\hline Hybrids & $\begin{array}{c}\text { Harvest age } \\
\text { (days) }\end{array}$ & $\begin{array}{c}\text { Height of } \\
\text { plant }(\mathrm{cm})\end{array}$ & $\begin{array}{c}\text { Amount of } \\
\text { Grain }(\%)\end{array}$ & $\begin{array}{c}\text { Forage dry } \\
\text { matter }\left(\mathrm{t} \mathrm{ha}^{-1}\right)\end{array}$ \\
\hline 9929030, 12F042226 & 106 & $88-121$ & $14-24$ & $14-16$ \\
\hline 12F042150, 9929012, 947216, 947072, 947252 & 118 & $128-191$ & $14-36$ & $16-27$ \\
\hline 947254, 12F042066, BRS Ponta Negra & 124 & $146-165$ & $17-30$ & $11-16$ \\
\hline
\end{tabular}

The material was processed using a stationary shredder forage machine set to $2-2.5 \mathrm{~cm}$ cuts and ensiled with compaction and approximate density of $550 \mathrm{~kg}$ of green mass $\mathrm{m}^{-3}$. Experimental cylindrical silos with $10 \mathrm{~cm}$ in diameter and $30 \mathrm{~cm}$ in length were used, which were sealed after filling. The silo opening occurred after 28 days, when a 20 g silage sample was collected for $\mathrm{pH}$ measurement and ammoniacal nitrogen $\left(\mathrm{NH}_{3}-\mathrm{N}\right)$ in relation to total nitrogen (dry matter basis) analysis. A composite sample of approximately $400 \mathrm{~g}$ was collected and subjected to pre-drying in an air drying oven at $55^{\circ} \mathrm{C}$ for $72 \mathrm{~h}$, followed by milling in a Wiley mill with a $1 \mathrm{~mm}$ sieve.

The pre-dried material was ground into $2 \mathrm{~mm}$ particles in a Wiley knife mill and packaged in plastic bottles for further analysis. A portion of the samples (triplicate) was ground to $1 \mathrm{~mm}$ for the following content analysis according to AOAC (1990): dry matter (DM: method $\left.n^{\circ} .934 .01\right)$, ether extract (EE: method $n^{\circ} .920 .39$ ) and crude protein (CP) according to the Kjeldahl method (method $n^{\circ}$. 981.10). The neutral detergent fiber (NDF) content was determined as described by Van Soest et al. (1991). Acid detergent fiber (ADF) contents were determined as described by Robertson and Van Soest (1981).

A portion of the silage (triplicate) was used while fresh for the $\mathrm{pH}$ evaluation (MIZUBUTI et al., 2009), performed with a $\mathrm{pH}$ meter (MA522 model, Marconi Laboratory Equipment, Piracicaba, Brazil). The ammonia nitrogen ( $\mathrm{mg} \mathrm{g}^{-1}$ total $\mathrm{N}$ ) content was determined as described by Bolsen et al. (1992).

For the in situ incubation of the silage of 10 double-purpose sorghum hybrids, a randomized block design with three replicates was used, with each animal representing a block: 9929030, 12F042150, 9929012, 947216, 947254, 947072, 
947252, 12F042066, 12F042226 and BRS Ponta Negra. The following criteria were used: precocity, productivity, morphological characteristics and presence of grain, according to Table 1 . The predried samples of the silages of these hybrids were ground in a Wiley mill (knife mill) using a $5 \mathrm{~mm}$ sieve, according to recommendations of incubations for silages proposed by Nocek (1988).

For the determination of the in situ degradability, three Santa Ines sheep (approximately 14 months of age, $35 \mathrm{~kg}$ of body weight) were used. The sheep were provided with permanent fistulated rumen cannulas and kept in individual pens. The animals were submitted to a period of adaptation for 14 days, during which concentrated feed and corn silage (40:60) were provided twice each morning. Water was available to the animals ad libitum. Ten doublepurpose sorghum hybrids were placed into TNTtype bags $(8 \times 5 \mathrm{~cm})$ in a quantity of approximately $20 \mathrm{mg}$ of $\mathrm{DM} \mathrm{cm} \mathrm{cm}^{-2}$ of surface area in the bag (NOCEK, 1988). Incubation periods of $0,6,12,24$, 48,72 and $96 \mathrm{~h}$ were used. The bags were placed in reverse order and in triplicate in each of the animals to ensure repetition for all animals and to promote uniformity. After each incubation period, the bags were removed from the rumen, washed thoroughly under running distilled water, and dried.

The in situ degradability of the DM and CP was determined using the weight difference for each component between the weighing carried out before and after ruminal incubation and was expressed as a percentage. After coefficients $a, b$, and $\mathrm{c}$ were obtained, these values were inserted into the equation proposed by Ørskov and McDonald (1979) to calculate the degradability:

$$
D t=a+b \times\left(1-e^{-c t}\right)
$$

in which $\mathrm{Dt}=$ the fraction potentially degraded at time $\mathrm{t}\left(\mathrm{g} 100^{-1} \mathrm{~g}\right), \mathrm{a}=$ the soluble fraction $\left(\mathrm{g} 100^{-1}\right.$ $\mathrm{g}), \mathrm{b}=$ the potentially degradable insoluble fraction $\left(\mathrm{g} 100^{-1} \mathrm{~g}\right), \mathrm{c}=$ the rate of degradation of fraction $\mathrm{b}$ (g $\left.100^{-1} \mathrm{~g} \mathrm{~h}^{-1}\right)$, and $\mathrm{t}=$ the time $\left(\mathrm{h}^{-1}\right)$. The nonlinear coefficients $\mathrm{a}, \mathrm{b}$ and $\mathrm{c}$ were estimated using Gauss-
Newton iterative procedures. The undegradable fraction (U) was calculated according to $\mathrm{U}$ (g 100-1 $\mathrm{g})=100-(\mathrm{a}+\mathrm{b})$.

To evaluate the effective degradability (ED), it was calculated with the mathematical model:

$$
\mathrm{ED}=\mathrm{a}+[(\mathrm{b} \times \mathrm{c}) /(\mathrm{c}+\mathrm{K})]
$$

where $\mathrm{K}=$ rate of passage of solids through the rumen, defined here as $2 \% / \mathrm{h}, 5 \% / \mathrm{h}$ and $8 \% / \mathrm{h}$, and related to the level of low, medium and high food intake, respectively.

The values of $\mathrm{pH}$, ammoniacal nitrogen and chemical composition were submitted to analysis of variance and analyzed by the Scott-Knot procedure at 5\% significance using SISVAR software version 5.6. The degradability data were analyzed by Tukey's test at 5\% significance, with the aid of SAS (Statistical Analysis System, version 9.2).

\section{Results and Discussion}

Dry matter (DM) content presented greater means in hybrids 9929012, 947216, 947030, 947254, 947072, 947252, 12F042066, 1141570 and 1141562, with values varying between 402.9 and $470.7 \mathrm{~g} \mathrm{~kg}^{-1}$ (Table 2). Of these hybrids, only the hybrid 1141570 was not ensiled with a DM above $350 \mathrm{~g} \mathrm{~kg}^{-1}$. The variation in the DM contents of the in natura material did not affect the $\mathrm{pH}$ values of the hybrid silages. According to Goeser et al. (2015), the DM losses in the fodder occur in the fermentation processes and even at silo opening; therefore, as the $\mathrm{pH}$ and $\mathrm{DM}$ content are strongly related, fodder with low DM contents (between 300 and $350 \mathrm{~g}$ $\mathrm{kg}^{-1}$ ) should be avoided for ensilage. In addition, plant silage with optimal DM content contributes to reduced concentrations of mycotoxins (LOUČKA et al., 2014; SCHMIDT et al., 2015).

Hybrids 947030, 947254 and 947072 presented greater $\mathrm{pH}(\mathrm{P}<0.001)$, with means of $4.49,4.46$ and 4.52, respectively, compared to the other hybrids (Table 2). Hybrids 947030, 947254 and 947072 
presented a $\mathrm{pH}$ above the ideal range for silage to be characterized as good quality. According to França et al. (2011), the silages characterized by good quality must have a $\mathrm{pH}$ of approximately 4.2 , which avoids proteolysis and the consequent production of butyric acid. This range can vary from 3.8 to
4.2 in ideal silage. Hybrids 9929036, 12F042150, FEPAGRO18, FEPAGRO11, 9929012, 9929026, 947216, 947252, SF15, SF25, PROG134IPA, 1141572, 12F042066, 12F042226, 1141570, BRS506, and BRS Ponta Negra had values within the optimal $\mathrm{pH}$ range.

Table 2. Chemical composition, ammoniacal nitrogen $\left(\mathrm{N}-\mathrm{NH}_{3}\right)$ and $\mathrm{pH}$ values of silage of dual-purpose sorghum hybrids $^{(1)}$.

\begin{tabular}{|c|c|c|c|c|c|c|c|}
\hline \multirow{2}{*}{ Sorghum Hybrids } & \multirow{2}{*}{$\mathrm{pH}$} & \multirow{2}{*}{$\mathrm{NH}_{3}-\mathrm{N}^{(2)}$} & \multicolumn{5}{|c|}{ Chemical composition $\left(\mathrm{g} \mathrm{kg}^{-1} \mathrm{DM}\right)$} \\
\hline & & & $\mathrm{DM}^{(3)}$ & $\mathrm{CP}^{(4)}$ & $\mathrm{EE}^{(5)}$ & $\mathrm{NDF}^{(6)}$ & $\mathrm{ADF}^{(7)}$ \\
\hline 9929036 & $3.9 \mathrm{c}$ & $0.1 \mathrm{~b}$ & $326 b$ & $54.7 \mathrm{a}$ & $19.4 \mathrm{c}$ & $710 \mathrm{~b}$ & $541 b$ \\
\hline 9929030 & $4.2 \mathrm{~b}$ & $0.1 \mathrm{~b}$ & $373 b$ & $59.7 \mathrm{a}$ & $20.4 \mathrm{c}$ & $678 \mathrm{c}$ & $493 b$ \\
\hline $12 \mathrm{~F} 042224$ & $3.5 \mathrm{~d}$ & $0.1 b$ & $354 \mathrm{~b}$ & $54.5 \mathrm{a}$ & $18.8 \mathrm{c}$ & $728 b$ & $471 \mathrm{c}$ \\
\hline $12 \mathrm{~F} 042150$ & $4.0 \mathrm{c}$ & $0.1 b$ & $328 b$ & $47.3 b$ & $16.1 \mathrm{c}$ & $711 \mathrm{~b}$ & $505 \mathrm{~b}$ \\
\hline FEPAGRO18 & $3.8 \mathrm{~d}$ & $0.2 \mathrm{a}$ & $339 b$ & $49.7 b$ & $15.5 \mathrm{c}$ & $672 \mathrm{c}$ & $464 c$ \\
\hline FEPAGRO19 & $3.7 \mathrm{~d}$ & $0.1 \mathrm{~b}$ & $357 \mathrm{~b}$ & $63.0 \mathrm{a}$ & $22.9 \mathrm{c}$ & $672 \mathrm{c}$ & $498 b$ \\
\hline FEPAGRO11 & $4.0 \mathrm{c}$ & $0.1 b$ & $330 \mathrm{~b}$ & $61.5 \mathrm{a}$ & $32.7 \mathrm{a}$ & $737 b$ & $462 \mathrm{c}$ \\
\hline 9929012 & $4.2 \mathrm{~b}$ & $0.1 b$ & $429 a$ & $52.1 \mathrm{~b}$ & $22.7 \mathrm{c}$ & $677 \mathrm{c}$ & $541 b$ \\
\hline 9929026 & $4.2 b$ & $0.1 b$ & $300 \mathrm{~b}$ & $56.2 \mathrm{a}$ & $16.7 \mathrm{c}$ & $685 \mathrm{c}$ & $527 \mathrm{~b}$ \\
\hline 947216 & $3.9 \mathrm{c}$ & $0.1 b$ & $404 a$ & $41.9 b$ & $14.7 \mathrm{c}$ & $644 d$ & $514 b$ \\
\hline 947030 & $4.5 \mathrm{a}$ & $0.1 b$ & $403 a$ & $60.7 \mathrm{a}$ & $26.9 b$ & $683 c$ & $508 \mathrm{~b}$ \\
\hline 947254 & $4.5 \mathrm{a}$ & $0.1 b$ & $425 \mathrm{a}$ & $45.1 \mathrm{~b}$ & $19.4 \mathrm{c}$ & $744 b$ & $528 \mathrm{~b}$ \\
\hline 947072 & $4.5 \mathrm{a}$ & $0.1 b$ & $465 \mathrm{a}$ & $63.0 \mathrm{a}$ & $18.1 \mathrm{c}$ & $717 b$ & $549 \mathrm{~b}$ \\
\hline 947252 & $4.2 \mathrm{~b}$ & $0.1 \mathrm{~b}$ & $416 \mathrm{a}$ & $60.9 a$ & $17.2 \mathrm{c}$ & $674 c$ & $437 \mathrm{c}$ \\
\hline SF15 & $3.8 \mathrm{c}$ & $0.2 \mathrm{a}$ & $354 b$ & $50.6 \mathrm{~b}$ & $32.7 \mathrm{a}$ & $655 \mathrm{~d}$ & $474 \mathrm{c}$ \\
\hline SF11 & $3.7 \mathrm{~d}$ & $0.1 \mathrm{~b}$ & $334 b$ & $40.9 b$ & $17.0 \mathrm{c}$ & $721 b$ & $522 \mathrm{~b}$ \\
\hline SF25 & $3.9 \mathrm{c}$ & $0.2 \mathrm{a}$ & $349 b$ & $40.8 \mathrm{~b}$ & $19.5 \mathrm{c}$ & $693 c$ & $530 \mathrm{~b}$ \\
\hline PROG134IPA & $3.9 \mathrm{c}$ & $0.1 b$ & $355 b$ & $51.2 \mathrm{~b}$ & $23.1 \mathrm{c}$ & $726 b$ & $555 b$ \\
\hline 1141572 & $4.2 b$ & $0.1 b$ & $354 \mathrm{~b}$ & $44.2 b$ & $23.6 \mathrm{c}$ & $823 a$ & $672 \mathrm{a}$ \\
\hline $12 \mathrm{~F} 042066$ & $4.2 b$ & $0.1 b$ & $472 \mathrm{a}$ & $47.5 b$ & $15.5 \mathrm{c}$ & $723 b$ & $497 b$ \\
\hline $12 \mathrm{~F} 042226$ & $4.1 b$ & $0.2 \mathrm{a}$ & $292 b$ & $59.9 \mathrm{a}$ & $28.6 b$ & $512 \mathrm{f}$ & $340 \mathrm{~d}$ \\
\hline 1141570 & $3.9 \mathrm{c}$ & $0.1 b$ & $432 \mathrm{a}$ & $40.6 b$ & $25.4 b$ & $761 b$ & $489 b$ \\
\hline 1141562 & $4.3 b$ & $0.1 b$ & $450 \mathrm{a}$ & $40.8 \mathrm{~b}$ & $33.9 \mathrm{a}$ & $588 \mathrm{e}$ & $504 \mathrm{~b}$ \\
\hline BRS506 & $4.0 \mathrm{c}$ & $0.2 \mathrm{a}$ & $348 b$ & $41.8 \mathrm{~b}$ & $10.9 \mathrm{c}$ & $623 d$ & $373 d$ \\
\hline BRS Ponta negra & $3.9 \mathrm{c}$ & $0.1 \mathrm{~b}$ & $326 \mathrm{~b}$ & $65.9 \mathrm{a}$ & $17.3 \mathrm{c}$ & $726 b$ & $573 b$ \\
\hline $\mathrm{CV}^{(8)}(\%)$ & 4.0 & 18.6 & 8.9 & 15.6 & 19.2 & 4.1 & 10.1 \\
\hline P-value & $<0.001$ & $<0.001$ & $<0.001$ & $<0.001$ & $<0.001$ & $<0.001$ & $<0.001$ \\
\hline
\end{tabular}

${ }^{(1)}$ Means followed by different letters in the same column differ by Scott-Knot test at $5 \%$ probability. ${ }^{(2)}$ Relation to total nitrogen (DM basis), ${ }^{(3)} \mathrm{DM}$ : Dry matter, ${ }^{(4)} \mathrm{CP}$ : Crude protein, ${ }^{(5)} \mathrm{EE}$ : Ether extract, ${ }^{(6)} \mathrm{NDF}$ : neutral detergent fiber, ${ }^{(7)} \mathrm{ADF}$ : acid detergent fiber, ${ }^{(8)} \mathrm{CV}$ : Coefficient of variation. 
For the ammoniacal nitrogen $\left(\mathrm{NH}_{3}-\mathrm{N}\right)$ contents, the sorghum silage of the hybrids FEPAGRO18, SF15, SF25, 12F042226 and BRS506 showed the greatest mean values. The values of ammoniacal nitrogen are within the range recommended by Neumann et al. (2009) ammoniacal nitrogen values lower than $10 \%$ relative to total nitrogen indicate that the fermentation process did not result in excessive protein breakdown in ammonia and that the amino acids constitute the major part of the non-protein nitrogen (NPN). Therefore, all hybrids presented values of ammoniacal nitrogen considered ideal for good-quality silage.

In relation to the $\mathrm{CP}$ contents, greater concentrations were observed for hybrids 9929036 , 9929030, 12F042224, FEPAGRO19, FEPAGRO11, 9929026, 947030, 947072, 947252, 12F042226 and BRS Ponta Negra, with averages ranging from 54.5 to $65.9 \mathrm{~g} \mathrm{~kg}^{-1}$. The CP contents for hybrids 9929036 , 9929030, 12F042224, FEPAGRO19, FEPAGRO11, 9929026, 947030, 947072, 947252, 12F042226 and BRS Ponta Negra exhibited values close to those found by França et al. (2011), who obtained an average value of sorghum silage of $68 \mathrm{~g} \mathrm{~kg}^{-1}$. During the ensiling process, nutrient losses occur due to aerobic respiration and as effluents. In this sense, hybrids with higher nutritional value should be tested positively, since even when losses occur, silages tend to have higher nutritional values, and the morphological characteristics among the hybrids may have influenced these results (Tabela 1).

Differences existed among the sorghum hybrid on EE, NDF and ADF $(\mathrm{P}<0.001)$. Sorghum hybrid 1141572 silage presented a greater NDF mean content $\left(823.3 \mathrm{~g} \mathrm{~kg}^{-1}\right)$. The greatest value of ADF in the sorghum silage was obtained from the 1141572 hybrid, which presented the lowest NDF content. In contrast, the lowest mean content was observed in the sorghum hybrid 12F042226 silage, with $512 \mathrm{~g}$ $\mathrm{kg}^{-1} \mathrm{NDF}$. The lowest levels of ADF were found in the silages of the 12F042226 and BRS506 hybrids, with 340 and $373 \mathrm{~g} \mathrm{~kg}^{-1}$, respectively.
The EE values obtained in the hybrids, with an average content of $52 \mathrm{~g} \mathrm{~kg}^{-1}$, were lower than those found in the silage from sorghum studied by Oliveira et al. (2010). The authors affirm that high $\mathrm{EE}$ in forage is a positive factor, since this extract can be an energy source for the animals.

In silage production, the whole plant is used, and sorghum tends to have a higher proportion of stem, which is reflected in the fiber content. Because sorghum plants present more lignified tissues than other morphological parts of the plant, the variations in fiber content among the hybrids can be explained (FUSTINI et al., 2017). The botanical diversity of the plant, as well as the state of maturity, influences these values (BELANCHE et al., 2014).

Sorghum silage of the hybrids 9929030, 947216, 947072, 947252, 12F042066 and 12F04222 presented greater DM disappearance $(\mathrm{P}<0.001)$ at 96 hours. The DM disappearance of the hybrid 9929012 silage was greater at time 0 however, it changed in the 6-hour incubation, with the silage of the hybrid 9929030 obtaining a greater average

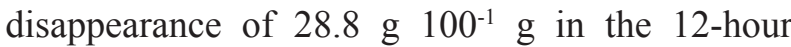
incubation period. The sorghum silages of the hybrids 9929030 and 9929012 showed greater DM disappearance, with averages of 32.8 and $32.1 \mathrm{~g}$ $100^{-1} \mathrm{~g}$, respectively (Table 3 ).

In the 24-hour incubation period, for determination of the DM disappearance, the sorghum silages of the hybrids 9929030, 9929012, 947072 and 947252 presented similar means, thus, these hybrids produced more rapidly disappearance silages. In the incubation period of 72 and 96 hours, besides the sorghum silages of the hybrids 947072 and 947252, the silages of the hybrids 9929030, 947216 and 12F042066 showed greater DM disappearance. Changes and differences in the degradation rate of the DM can be caused by differences in the cell wall structure of the evaluated sorghums, mainly in the cellulose content (GUIMARÃES JÚNIOR et al., 2010). Sorghum silages of the 12F042150, 947254 and BRS Ponta 
Negra hybrids presented slow disappearance rates of DM during the whole incubation period.

The sorghum silage of hybrids 9929030, 12F042150, 947072, 947252, 12F042066, $12 \mathrm{~F} 042226$ and BRS Ponta Negra presented greater $\mathrm{CP}$ disappearance $(\mathrm{P}<0.05)$, ranging from 67.8 to

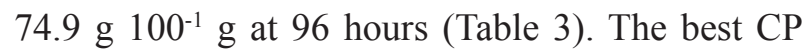
disappearance means were observed in the sorghum hybrid 947252 silage over the incubation time and in the hybrid 9929030 silage in the 6-hour incubation period, indicating that these hybrids undergo faster disappearance. According to Guimarães Júnior et al. (2010), the differences observed among silages can be attributed to several factors such as the crop, the evaluated varieties, the management used in the cutting and silage, and the environmental conditions such as climate and soil where the plants are grown.

Table 3. Mean disappearance of dry matter (DM) and Crude Protein (CP) from dual purpose sorghum hybrids silage, as a function of ruminal incubation time ${ }^{(1)}$.

\begin{tabular}{|c|c|c|c|c|c|c|c|}
\hline \multirow{2}{*}{ Sorghum hybrids } & \multicolumn{7}{|c|}{ Disappearance as a function of time (h) $\mathrm{g} 100^{-1} \mathrm{~g}$} \\
\hline & 0 & 6 & 12 & 24 & 48 & 72 & 96 \\
\hline \multicolumn{8}{|c|}{ Dry Matter } \\
\hline 9929030 & $20.6 \mathrm{ab}$ & $28.8 \mathrm{a}$ & $32.8 \mathrm{a}$ & $39.2 \mathrm{a}$ & $45.8 \mathrm{ab}$ & $54.9 \mathrm{a}$ & $61.1 \mathrm{a}$ \\
\hline $12 \mathrm{~F} 042150$ & $18.4 \mathrm{~b}$ & $25.3 \mathrm{ab}$ & $28.3 \mathrm{ab}$ & $34.8 \mathrm{ab}$ & $39.4 \mathrm{ab}$ & $46.0 \mathrm{~b}$ & $53.5 \mathrm{ab}$ \\
\hline 9929012 & $23.1 \mathrm{a}$ & $26.3 \mathrm{ab}$ & $32.0 \mathrm{a}$ & $36.6 \mathrm{a}$ & $41.3 \mathrm{ab}$ & $49.4 \mathrm{ab}$ & $53.2 \mathrm{ab}$ \\
\hline 947216 & $20.6 \mathrm{ab}$ & 23.9ab & $28.2 \mathrm{ab}$ & $32.5 \mathrm{ab}$ & $45.0 \mathrm{ab}$ & $51.7 \mathrm{a}$ & $56.0 \mathrm{a}$ \\
\hline 947254 & $16.0 \mathrm{~b}$ & $18.4 b$ & $23.0 \mathrm{~b}$ & $28.1 \mathrm{~b}$ & $34.7 b$ & $45.8 \mathrm{~b}$ & $49.6 b$ \\
\hline 947072 & $17.0 \mathrm{~b}$ & $21.5 \mathrm{ab}$ & $26.8 \mathrm{ab}$ & $37.1 \mathrm{a}$ & $48.5 \mathrm{a}$ & $53.6 \mathrm{a}$ & $65.9 \mathrm{a}$ \\
\hline 947252 & $17.7 \mathrm{~b}$ & $21.1 \mathrm{ab}$ & $27.3 \mathrm{ab}$ & $38.0 \mathrm{a}$ & $49.3 \mathrm{a}$ & $55.6 \mathrm{a}$ & $61.5 \mathrm{a}$ \\
\hline $12 \mathrm{~F} 042066$ & $17.1 \mathrm{~b}$ & $20.3 \mathrm{ab}$ & $27.8 \mathrm{ab}$ & $33.4 \mathrm{ab}$ & $40.9 \mathrm{ab}$ & $51.0 \mathrm{a}$ & $59.3 \mathrm{a}$ \\
\hline $12 \mathrm{~F} 042226$ & $17.2 \mathrm{~b}$ & $21.4 \mathrm{ab}$ & $27.1 \mathrm{ab}$ & $32.5 \mathrm{ab}$ & $42.1 \mathrm{ab}$ & $49.1 \mathrm{ab}$ & $58.7 \mathrm{a}$ \\
\hline BRS Ponta Negra & $13.2 \mathrm{~b}$ & $17.6 \mathrm{~b}$ & $23.8 \mathrm{~b}$ & $28.6 b$ & $35.4 \mathrm{~b}$ & $49.2 \mathrm{ab}$ & $51.8 \mathrm{~b}$ \\
\hline $\mathrm{CV}^{(2)}(\%)$ & 7.3 & 10.0 & 9.4 & 8.9 & 8.6 & 9.1 & 8.7 \\
\hline P-value & $<0.001$ & $<0.001$ & $<0.001$ & $<0.001$ & $<0.001$ & $<0.001$ & $<0.001$ \\
\hline \multicolumn{8}{|c|}{ Crude Protein } \\
\hline 9929030 & $25.7 b$ & $41.5 \mathrm{a}$ & $51.4 \mathrm{a}$ & $53.2 \mathrm{a}$ & $58.8 \mathrm{a}$ & $66.8 \mathrm{a}$ & $71.2 \mathrm{a}$ \\
\hline $12 \mathrm{~F} 042150$ & $22.0 \mathrm{~b}$ & $37.9 \mathrm{ab}$ & $43.6 b$ & $49.3 \mathrm{a}$ & $56.6 \mathrm{ab}$ & $64.4 \mathrm{a}$ & $71.4 \mathrm{a}$ \\
\hline 9929012 & $25.4 \mathrm{~b}$ & $26.1 \mathrm{~b}$ & $29.2 \mathrm{c}$ & $32.4 \mathrm{c}$ & $35.3 \mathrm{c}$ & $37.6 \mathrm{~b}$ & $42.5 b$ \\
\hline 947216 & $24.8 b$ & $29.2 b$ & $34.4 \mathrm{c}$ & $40.3 b$ & $52.8 \mathrm{~b}$ & $59.7 \mathrm{a}$ & $63.9 \mathrm{ab}$ \\
\hline 947254 & $19.4 \mathrm{ab}$ & $24.0 \mathrm{~b}$ & $31.9 \mathrm{c}$ & $39.3 b c$ & $47.4 b$ & $58.6 \mathrm{a}$ & $61.9 \mathrm{ab}$ \\
\hline 947072 & $16.9 \mathrm{c}$ & $28.9 b$ & $34.3 \mathrm{c}$ & $41.7 \mathrm{~b}$ & $58.3 \mathrm{a}$ & $66.8 \mathrm{a}$ & $74.9 \mathrm{a}$ \\
\hline 947252 & $32.9 a$ & $45.3 \mathrm{a}$ & $49.7 \mathrm{a}$ & $54.0 \mathrm{a}$ & $59.1 \mathrm{a}$ & $63.4 \mathrm{a}$ & $70.4 \mathrm{a}$ \\
\hline $12 \mathrm{~F} 042066$ & $24.4 \mathrm{~b}$ & $30.6 b$ & $40.0 \mathrm{~b}$ & $46.8 \mathrm{ab}$ & $53.2 \mathrm{ab}$ & $63.3 \mathrm{a}$ & $69.8 \mathrm{a}$ \\
\hline $12 \mathrm{~F} 042226$ & $23.0 \mathrm{~b}$ & $29.6 b$ & $35.7 \mathrm{c}$ & $43.0 \mathrm{~b}$ & $51.7 \mathrm{~b}$ & $59.2 \mathrm{a}$ & $68.1 \mathrm{a}$ \\
\hline BRS Ponta Negra & $25.7 b$ & $34.1 \mathrm{ab}$ & $42.3 b$ & $46.7 \mathrm{ab}$ & $53.7 \mathrm{ab}$ & $64.4 \mathrm{a}$ & $67.8 \mathrm{a}$ \\
\hline CV $(\%)$ & 8.6 & 9.1 & 9.1 & 8.4 & 9.1 & 10.0 & 9.1 \\
\hline P-value & 0.027 & $<0.001$ & $<0.001$ & 0.005 & 0.009 & $<0.001$ & $<0.001$ \\
\hline
\end{tabular}

${ }^{(1)}$ Means followed by different letters in the same column differ by Tukey's test at $5 \%$ probability. ${ }^{(2)} \mathrm{CV}$ : Coefficient of variation. 
The sorghum silage of the hybrid 947072 was highlighted, which retained greater CPdisappearance values throughout the incubation period. In contrast, the sorghum silage of the BRS Ponta Negra hybrid presented the lowest performance for disappearance among the silages tested for the entire incubation period. According to Goes et al. (2012), this variation can be attributed to the specific characteristics of the protein, accessibility to the digestible enzymes or presence of antinutritional substances.
For the DM fractions, the sorghum silages of the hybrids 9929030 and 9929012 presented greater $(\mathrm{P}=$ 0.003 ) soluble fraction " $a$ " concentrations of 22.5 and

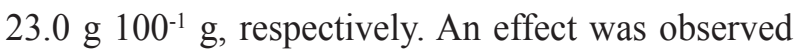
on fraction " $\mathrm{b}$ " ( $\mathrm{P}=0.013)$ for DM degradability, with mean values ranging from 42.0 to $80.4 \mathrm{~g} 100^{-1} \mathrm{~g}$. The sorghum silages of the hybrids 9929012,947216 and 947252 were greater $(\mathrm{P}<0.001)$ for the undegradable fraction "U" of the DM, with average values 35.0,

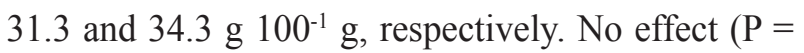
0.152 ) was observed for the "c" fraction or for the rate of degradation of fraction " $b$ " (Table 4).

Table 4. Soluble fraction (a), potentially degradable (b), rate of degradation of fraction " $b$ " (c) (expressed in $g$ 100-1 $g$ $\left.\mathrm{h}^{-1}\right)$ and non-degradable fraction (U) of dual purpose sorghum hybrids silages ${ }^{(1)}$.

\begin{tabular}{|c|c|c|c|c|}
\hline \multirow{2}{*}{ Sorghum hybrids } & \multicolumn{4}{|c|}{ Fraction of degradation $\left(\mathrm{g} 100^{-1} \mathrm{~g}\right)$} \\
\hline & "a" & "b" & "c" & “U” \\
\hline \multicolumn{5}{|c|}{ Dry Matter } \\
\hline 9929030 & $22.5 \mathrm{a}$ & $67.8 b$ & 0.008 & $9.63 \mathrm{c}$ \\
\hline $12 \mathrm{~F} 042150$ & $18.4 \mathrm{~b}$ & $78.8 \mathrm{a}$ & 0.005 & $2.75 \mathrm{~d}$ \\
\hline 9929012 & $23.0 \mathrm{a}$ & $42.0 \mathrm{c}$ & 0.013 & $35.0 \mathrm{a}$ \\
\hline 947216 & $20.6 \mathrm{ab}$ & $48.1 \mathrm{c}$ & 0.014 & $31.3 \mathrm{a}$ \\
\hline 947254 & $16.0 \mathrm{~b}$ & $60.0 \mathrm{bc}$ & 0.009 & $24.0 \mathrm{~b}$ \\
\hline 947072 & $17.0 \mathrm{~b}$ & $65.6 b$ & 0.013 & $17.4 \mathrm{bc}$ \\
\hline 947252 & $17.7 \mathrm{~b}$ & $47.9 \mathrm{c}$ & 0.024 & $34.3 \mathrm{a}$ \\
\hline $12 \mathrm{~F} 042066$ & $17.1 \mathrm{~b}$ & $80.4 \mathrm{a}$ & 0.007 & $2.41 \mathrm{~d}$ \\
\hline $12 \mathrm{~F} 042226$ & $17.2 b$ & $80.1 \mathrm{a}$ & 0.007 & $2.70 \mathrm{~d}$ \\
\hline BRS Ponta Negra & $13.2 \mathrm{c}$ & $65.5 b$ & 0.009 & $12.1 \mathrm{c}$ \\
\hline $\mathrm{CV}^{(2)}(\%)$ & 8.8 & 9.5 & 9.0 & 9.0 \\
\hline P-value & 0.003 & 0.013 & 0.152 & $<0.001$ \\
\hline \multicolumn{5}{|c|}{ Crude Protein } \\
\hline 9929030 & $27.3 \mathrm{ab}$ & $54.6 \mathrm{~b}$ & $0.014 \mathrm{ab}$ & $18.1 \mathrm{c}$ \\
\hline $12 \mathrm{~F} 042150$ & $23.1 \mathrm{~b}$ & $68.8 \mathrm{ab}$ & $0.010 \mathrm{~b}$ & $8.14 d$ \\
\hline 9929012 & $25.4 \mathrm{~b}$ & $26.2 d$ & $0.010 \mathrm{~b}$ & $48.4 \mathrm{a}$ \\
\hline 947216 & $24.8 b$ & $47.9 \mathrm{c}$ & $0.018 \mathrm{a}$ & $27.2 b$ \\
\hline 947254 & $19.4 \mathrm{bc}$ & $51.4 b c$ & $0.018 \mathrm{a}$ & $29.2 b$ \\
\hline 947072 & $16.9 \mathrm{c}$ & $77.2 \mathrm{a}$ & $0.014 \mathrm{ab}$ & $5.93 d$ \\
\hline 947252 & $32.9 \mathrm{a}$ & $59.2 b$ & $0.008 \mathrm{~b}$ & $7.87 \mathrm{~d}$ \\
\hline $12 \mathrm{~F} 042066$ & $24.4 \mathrm{~b}$ & $57.9 b$ & $0.015 \mathrm{a}$ & $17.7 \mathrm{c}$ \\
\hline $12 \mathrm{~F} 042226$ & $23.0 \mathrm{~b}$ & $66.0 \mathrm{ab}$ & $0.011 b$ & $10.9 \mathrm{~cd}$ \\
\hline BRS Ponta Negra & $25.72 b$ & $54.77 \mathrm{~b}$ & $0.014 \mathrm{a}$ & $19.5 \mathrm{c}$ \\
\hline CV $(\%)$ & 9.1 & 8.1 & 8.9 & 9.5 \\
\hline P-value & 0.005 & $<0.001$ & 0.041 & 0.008 \\
\hline
\end{tabular}

${ }^{(1)}$ Means followed by different letters in the same column differ by Tukey's test at $5 \%$ probability. ${ }^{(2)} \mathrm{CV}$ : Coefficient of variation. 
The sorghum silages of the hybrids 9929030 and 9929012 had greater soluble fraction "a" concentrations. As the greatest DM soluble fraction, "a" can provide the nutrients present in the silage to the rumen microorganisms faster consequently, this fraction tends to be degraded in less time. For example, the larger the value is for fraction "a", the greater the feed degradation (GUIMARÃES JÚNIOR et al., 2010; CARDOSO et al., 2012).

The greatest concentrations of the potentially degradable fraction " $b$ " of the DM were obtained in the silages of the 12F042150, 12F042066 and 12F042226 hybrids thus, these hybrids have greater DM degradation. According to Cardoso et al. (2012), in research on silages with three genotypes of sorghum, average values of the potentially degraded fraction varied from 43.4 to $53.8 \mathrm{~g} 100^{-1}$ $\mathrm{g}$, which were lower than those from the study on the hybrids compared herein.

Sorghum hybrid 9929012 silage had the greatest fraction "U", which resulted from lower average degradation of fractions "a" and " $b$ ", proving that the CP degradation of silage requires a longer period for degradation. The greater the fraction " $U$ " is, the longer the silage needs to pass in the rumen for the DM to be degraded. The silages of the $12 \mathrm{~F} 042150,12 \mathrm{~F} 042066$ and 12F042226 showed faster degradation because of the values of fraction "U".

Variations obtained in the $\mathrm{CP}$ degradation fraction show the superiority of the soluble fraction "a" for the hybrid 947072, which allowed acquisition of a considerable value for fraction " $b$ ". The silage of the hybrid 9929012 showed lower CP degradation and did not stand out during the incubation period. The undegradable fraction values were obtained at lower values only for the 12F042150, 947072 and 947252 hybrids, thus indicating that these hybrids were more degradable however, the degradation rate was still slow. However, the effect on the "c" degradation rate $(\mathrm{P}=0.041)$ of the crude protein was higher in the silages of the hybrids 947216,947254 , 12F042066 e BRS Ponta Negra with variations of

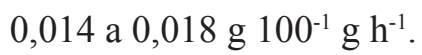

The effective degradability presented reduction in the times (2, 5 and 8 hours) for all hybrids in the dry matter and crude protein contents (Table 5). Pires et al. (2010) observed a similar effect, in corn, sorghum and Brachiaria silages for effective degradability of dry matter and crude protein.

Table 5. Effective degradability in silage of dual-purpose sorghum hybrids.

\begin{tabular}{lccc}
\hline \multirow{2}{*}{ Sorghum hybrids } & \multicolumn{3}{c}{ Effective Degradability $\left({\left.\mathrm{g} 100^{-1} \mathrm{~g} \mathrm{~h}^{-1}\right)}\right.$} \\
\cline { 2 - 4 } & 2 & 5 & 8 \\
\hline & \multicolumn{3}{c}{ Dry Matter } \\
\cline { 2 - 4 } 12 F042150 & 45.2 & 36.3 & 34.0 \\
9929012 & 40.0 & 33.5 & 33.3 \\
947216 & 40.5 & 33.2 & 30.7 \\
947254 & 40.2 & 30.7 & 27.2 \\
947072 & 34.3 & 25.0 & 22.0 \\
947252 & 43.2 & 31.0 & 26.7 \\
12 F042066 & 42.6 & 31.4 & 26.7 \\
12 F042226 & 40.3 & 29.4 & 26.1 \\
BRS Ponta Negra & 40.0 & 29.5 & 26.4 \\
\hline & 35.6 & 25.6 & 22.4
\end{tabular}


continuation

\begin{tabular}{lccc}
\hline & \multicolumn{3}{c}{ Crude Protein } \\
\cline { 2 - 4 } 9929030 & 61.7 & 62.7 & 54.3 \\
$12 \mathrm{~F} 042150$ & 58.2 & 56.2 & 54.8 \\
9929012 & 34.3 & 30.0 & 28.5 \\
947216 & 47.3 & 37.1 & 33.2 \\
947254 & 44.4 & 33.9 & 29.7 \\
947072 & 52.3 & 39.5 & 35.5 \\
947252 & 62.0 & 65.5 & 62.9 \\
$12 F 042066$ & 51.6 & 41.6 & 38.3 \\
$12 F 042226$ & 49.2 & 39.0 & 35.9 \\
BRS Ponta Negra & 52.8 & 44.6 & 42.5 \\
\hline
\end{tabular}

Descriptive data analysis.

\section{Conclusions}

The silages of the hybrids 9929036, 12F042224, FEPAGRO11, 9929026 and BRS Ponta Negra obtained better results only for the chemical composition, and hybrids 947072, 947252 and 12F042066, only for degradability.

The use of hybrids 9929030 and 12F042226 is recommended because they present silage with a better chemical composition of DM, CP and NDF and better degradability of DM and CP.

\section{References}

ANDRADE JUNIOR, A. S.; BASTOS, E. A.; BARROS, A. H. C.; SILVA, C. O.; GOMES, A. A. N. Classificação climática do Estado do Piauí. Teresina: EMBRAPA Meio-Norte, 2004. 86 p.

ARGENTA, F. M.; BRONDANI, I. L.; ALVES FILHO, D. C.; RESTLE, J.; SEGABINAZZI, L. R.; CATTELAM, J.; SILVA, V. S.; PAULA, P. C.; AZEVEDO JÚNIOR, R. L.; KLEIN, J. L.; ADAMS, S. M.; TEIXEIRA, O. S. Steers performance fed diets with Alexander grass silage (Urochloa plantaginea) x sorghum silage (Sorghum bicolor (L.) Moench). Semina: Ciências Agrárias, Londrina, v. 35, n. 2, p. 951-962, 2014. DOI: $10.5433 / 1679-0359.2014 \mathrm{v} 35 \mathrm{n} 2 \mathrm{p} 951$

ASSOCIATION OF OFFICIAL ANALYTICAL CHEMISTS - AOAC. Official methods of analysis. $15^{\text {th }}$ ed. Arlington: AOAC International, 1990. 1117 p.

AVELINO, P. M.; NEIVA, J. M. N.; ARAÚJO, V. L.;
ALEXANDRINO, E.; BOMFIM, M. A. D.; RESTLE, J. Chemical composition of silage sorghum hybrids grown at different densities. Revista Ciência Agronômica, Fortaleza, v. 42, n. 1, p. 208-215, 2011. DOI: 10.1590/ S1806-66902011000100026

BELANCHE, A.; WEISBJERG, M. R.; ALLISON, G. G.; NEWBOLD, C. J.; MOORBY, J. M. Measurement of rumen dry matter and neutral detergent fiber degradability of feeds by Fourier-transform infrared spectroscopy. Journal of Dairy Science, Champaign, v. 97, n. 4, p. 2361-2375, 2014. DOI: 10.3168/jds.2013-7491

BOLSEN, K. K.; LIN, C.; BRENT, C. R.; FEYERHERM, A. M.; URBAN, J. E.; AIMUTIS, W. R. Effect of silage additives on the microbial succession and fermentation process of alfalfa and corn silages. Journal of Dairy Science, Champaign, v. 75, n. 11, p. 3066-3083, 1992. DOI: $10.3168 /$ jds.S0022-0302(92)78070-9

CARDOSO, R. M.; PIRES, D. A. A.; ROCHA JÚNIOR, V. R.; REIS, S. T.; SALES, R. C. J.; ALVES, D. D.; GERASSEV, L. C.; RODRIGUES, J. A. S.; LIMA, L. O. B. Evaluation of hybrid sorghum for silage through in situ degradability. Revista Brasileira de Milho e Sorgo, Sete Lagoas, v. 11, n. 1, p. 106-114, 2012. DOI: 10.18512/1980-6477/rbms.v11n1p106-114

CAVALCANTE, D. R.; PERIN, F. B.; BENEDETTI, E. In situ dry matter degradability of three tropical forages of green chopped and ensiled forms. Arquivos Brasileiro de Medicina Veterinária e Zootecnia, Belo Horizonte, v. 64, n. 1 , p. $163-168,2012$. DOI: 10.1590/S010209352012000100023

FRANÇA, A. F. S.; OLIVEIRA, R. P.; RODRIGUES, J. A. S.; MIYAGI, E. S.; SILVA, A. G.; PERON, H. J. M. C.; ABREU, J. B. R.; BASTOS, D. C. Fermentative 
characteristics of sorghum hybrids ensilage under nitrogen rates. Ciência Animal Brasileira, Goiânia, v. 12, n. 3, p. 383-391, 2011. DOI: 5216/cab.v12i3.540

FUSTINI, M.; PALMONARI, A.; CANESTRARI, G.; BONFANTE, E.; MAMMI, L.; PACCHIOLI, M. T.; SNIFFEN, G. C. J.; GRANT, R. J.; COTANCH, K. W.; FORMIGONI, A. Effect of undigested neutral detergent fiber content of alfalfa hay on lactating dairy cows: feeding behavior, fiber digestibility, and lactation performance. Journal of Dairy Science, Illinois, v. 100, n. 6, p. 1-9, 2017. DOI: 10.3168/jds.2016-12266

GOES, R. H. T. B.; TRAMONTINI, R. C. M.; CARDIM, S. T.; ALMEIDA, G. D.; RIBEIRO, J.; MOROTTI, F.; OLIVEIRA, L. A.; BRABES, K. C. S. Ruminal degradability of dry matter and crude protein of roughages for cattle. Revista Acadêmica: Ciências Agrárias e Ambientais, Curitiba, v. 10, n. 3, p. 285-291, 2012. DOI: 10.7213/academica.7709

GOESER, J. P.; HEUER, C. R.; CRUMP, P. M. Forage fermentation product measures are related to dry matter loss through meta-analysis. The Professional Animal Scientist, Illinois, v. 31, n. 2, p. 137-145, 2015. DOI: 10.15232/pas.2014-01356

GUIMARÃES JÚNIOR, R.; GONÇALVES, L. C.; JAYME, D. G.; PIRES, D. A. A.; RODRIGUES, J. A. S.; TOMICH, T. R. In situ degradabilities of pearl millet silages in sheep. Ciência Animal Brasileira, Goiânia, v. 11, n. 2, p. 334-343, 2010. DOI: 10.526/cab.v11i2.7053

LIU, P.; YIN, L.; DENG, X.; WANG, S.; TANAKA, $\mathrm{K}$; ZHANG, S. Aquaporin-mediated increase in root hydraulic conductance is involved in silicon-induced improved root water uptake under osmotic stress in Sorghum bicolor L. Journal of Experimental Botany, Oxford, v. 65, n. 17, p. 4747-4756, 2014. DOI: 10.1093/ jxb/eru220

LOUČKA, R.; HAKL, J.; JIRMANOVÁ, J.; TYROLOVÁ, Y. Yearly variation in maize silage fermentation and nutritive quality. Grass and Forage Science, Londres, v. 70, n. 4, p. 674-681, 2014. DOI: $10.1111 /$ gfs. 12151

MIZUBUTI, I. Y.; PINTO, A. P.; PEREIRA, E. S.; RAMOS, B. M. O. Métodos laboratoriais de avaliação de alimentos para animais. Londrina: EDUEL, 2009. $228 \mathrm{p}$.

NEUMANN, M.; OLIBONI, R.; OLIVEIRA, M. R.; GÓRSKI, S. C.; FARIA, M. V.; UENO, R. K.; MARAFON, F. Sunflower (Helianthus annuus L.) for production of silage of the entire plant. Pesquisa Aplicada \& Agrotecnologia, Guarapuava, v. 2, n. 3, p. 191-202, 2009. Disponível em: https://revistas.unicentro.br/index.
php/repaa/article/view\%20File/1513/1390. Acesso em: 05 de abr. 2017.

NOCEK, J. E. In situ and others methods to estimate ruminal protein and energy digestibility. Journal of Dairy Science, Illinois, v. 71, n. 8, p. 2051-2069, 1988. DOI: 10.3168/jds.S0022-0302(88)79781-7

OLIVEIRA, L. B.; PIRES, A. J. V.; CARVALHO, G. G. P.; RIBEIRO, L. S. O.; ALMEIDA, V. V.; PEIXOTO, C. A. M. Losses and nutritional value of corn, Sudan sorghum, forage sorghum and sunflower silages. Revista Brasileira de Zootecnia, Viçosa, MG, v. 39, n. 1, p. 6167, 2010. DOI: 10.1590/S1516-35982010000100008

ØRSKOV, E. R.; MCDONALD, I. The estimation of protein degradability in the rumen from incubation measurements weighted according to rate of passage. Journal of Agricultural Science, Toronto, v. 92, n. 2, p. 499-508, 1979. DOI: 10.1017/S0021859600063048

PIRES, A. J. V.; REIS, R. A.; CARVALHO, G. G. P.; SIQUEIRA, G. R.; BERNARDES, T. F.; RUGGIERI, A. C.; ROTH, M. T. P. Degradabilidade ruminal da matéria seca, da proteína bruta e da fração fibrosa de silagens de milho, de sorgo e de Brachiaria brizantha. Arquivo Brasileiro de Medicina Veterinária e Zootecnia, Belo Horizonte, v. 62, n. 2, p. 391-400, 2010. DOI: 10.1590/ S0102-09352010000200020

PIRES, D. A. A.; GONÇALVES, L. C.; RODRIGUES, J. A. S.; JAYME, D. G.; GUIMARÃES JÚNIOR, R.; RODRIGUEZ, N. M.; BORGES, I.; BORGES, A. L. C. C.; JAYME, C. G.; BOTELHO, P. R. F.; LIMA, L. O. B. In situ degradability of the fibrous fractions of sorghum silage. Revista Brasileira de Milho e Sorgo, Sete Lagoas, v. 8, n. 2, p. 175-185, 2009. DOI: 10.18512/1980-6477/ rbms.v8n2p175-185

RIBAS, P. M. Cultivo de sorgo. 3. ed. Sete Lagoas: EMBRAPA Milho e Sorgo2007. 4 p. (Sistemas de Produção 2).

ROBERTSON, J. B.; VAN SOEST, P. J. The detergent system of analysis. In: JAMES, W. P. T.; THEANDER, O. (Ed.). The analysis of dietary fibre in food. New York: Marcel Dekker, 1981. p. 23-158.

SCHMIDT, P.; NOVINSKI, C. O.; JUNGES, D.; ALMEIDA, R.; SOUZA, C. M. Concentration of mycotoxins and chemical composition of corn silage: a farm survey using infrared thermography. Journal of Dairy Science, Illinois, v. 98, n. 9, p. 6609-6619, 2015. DOI: $10.3168 /$ jds.2014-8617

SOUSA, D. M. G.; LOBATO, E. Cerrado: correção do solo e adubação. Brasília: EMBRAPA Cerrados, 2004. $416 \mathrm{p}$. 
SUZUKI, T.; SAKAIGAICHI, T.; TERAJIMA, Y.; MATSUOKA, M.; KAMIYA, Y.; HATTORI, I.; TANAKA, M. Chemical composition and in situ degradability of two varieties of sugarcane at different growth stages in subtropical Japan. Grassland Science, Tokyo, v. 56, n. 3, p. 134-140, 2010. DOI: 10.1111/j.1744697X.2010.00185.X

THOMAS, M. E.; FOSTER, J. L.; MCCUISTION, K. C.; REDMON, L. A.; JESSUP, R. W. Nutritive value, fermentation characteristics, and in situ disappearance kinetics of sorghum silage treated with inoculants. Journal of Dairy Science, Illinois, v. 96, n. 11, p. 71207131, 2013. DOI: 10.3168/jds.2013-6635

VAN SOEST, P. J.; ROBERTSON, J. B.; LEWIS, B. A. Methods for dietary fiber, neutral detergent fiber, and nonstarch polysaccharides in relation to animal nutrition. Journal of Dairy Science, Illinois, v. 74, n. 10, p. 35833597, 1991. DOI: 10.3168/jds.S0022-0302(91)78551-2 